\title{
Clinical characteristics and functional outcome of pediatric ocular trauma in a third level reference hospital in Guadalajara, Mexico
}

\author{
Luz C. Zepeda-Romero ${ }^{1,2 *}$, Laura R. Saucedo-Rodríguez ${ }^{2,3}$, Miriam Becerra-Cota ${ }^{2,3}$, \\ José A. Gutiérrez-Padilla, ${ }^{2,4}$, Guillermo Yanowsky-Reyes ${ }^{1,2}$, Daniel Pérez-Rulfo-Ibarra ${ }^{2,5}$, \\ Nathalie Díaz-Borrayo ${ }^{1,2}$, Nayeli N. Cabrera-Díaz ${ }^{1,2}$, and Juan C. Barrera-de-León ${ }^{2,6}$
}

${ }^{1}$ Oftalmología Neonatal, Cirugía Pediátrica, Hospital Civil de Guadalajara Fray Antonio Alcalde; ${ }^{2}$ Centro Universitario de Ciencias de la Salud, Universidad de Guadalajara; ${ }^{3}$ Unidad de Oftalmología, Hospital Civil de Guadalajara Fray Antonio Alcalde; ${ }^{4}$ Direccion Sectorial de Investigación, Secretaría de Salud, Gobierno de Jalisco; ${ }^{5}$ Posgrado en Pediatría, Hospital Civil de Guadalajara; ${ }^{6}$ Unidad Médica de Alta Especialidad en Pediatría, Centro Médico Nacional de Occidente, Instituto Mexicano del Seguro Social. Guadalajara, Jalisco, Mexico

\begin{abstract}
Background: Ocular trauma is one of the leading causes of decreased visual acuity and monocular blindness in the pediatric population. Since its occurrence is potentially preventable, it is essential to understand its demographic characteristics and risk factors to alert and implement prevention and health promotion programs. Methods: We conducted a retrospective study in which we reviewed 187 clinical records of patients $\leq 15$ years old with the diagnosis of severe ocular trauma admitted in 2017 to the Hospital Civil de Guadalajara. We analyzed demographic variables, circumstances of the event, type of treatment, and the evolution of visual acuity and complications. Results: In total, 187 patients and 188 eyes were included; the average age was $6.99 \pm 4.1$ years. Children of 2 to 5 years of age $(41 \%)$ were the most affected, and a higher occurrence was observed in males (73\%). Open ocular trauma was the most common type of injury (72.7\%) caused by sharp objects (45.4\%). Most injuries occurred at home (78.1\%), without adult supervision (48.1\%), and during leisure time (74.9\%). Most events were accidental (80.4\%), although $12.3 \%$ were direct aggression. Surgery was required in 179 patients, in whom corneal injury repair (43.2\%) was the most commonly used procedure. Final visual acuity was quantified in 132 eyes, and visual acuity <20/200 was found in $18.1 \%$. Loss of $4.2 \%$ of the eyeballs was recorded. Conclusions: The highest proportion of cases was identified in male patients $\leq 5$ years old, unsupervised by an adult. Many eye injuries are preventable, so it is necessary to implement socio-educational programs in alliance with pediatric organizations that alert the severity of the problem and promote safe environments.
\end{abstract}

Keywords: Eye trauma. Monocular blindness. Health promotion.

\section{Características clínicas y resultados funcionales del trauma ocular pediátrico en un hospital de referencia de tercer nivel en Guadalajara, México}

\section{Resumen}

Introducción: El trauma ocular es una de las principales causas de disminución de la agudeza visual y de ceguera monocular en la población pediátrica. Su ocurrencia es potencialmente prevenible, por lo que es importante entender sus características demográficas y riesgos para alertar e implementar programas enfocados hacia la prevención y la promoción de

\section{Correspondence:}

*Luz C. Zepeda-Romero

E-mail: drconsuelo@yahoo.com

Available online: 24-01-2022

Date of reception: 21-04-2021

Date of acceptance: 14-09-2021

DOI: 10.24875/BMHIM.21000077
Bol Med Hosp Infant Mex. 2022;79(1):26-32

www.bmhim.com 1665-1146/C 2021 Hospital Infantil de México Federico Gómez. Published by Permanyer. This is an open access article under the CC BY-NC-ND license (http://creativecommons.org/licenses/by-nc-nd/4.0/). 
la salud. Métodos: Estudio retrospectivo en el que se analizaron 187 expedientes de pacientes $\leq 15$ años con diagnóstico de trauma ocular grave ingresados en 2017 al Hospital Civil de Guadalajara. Se analizaron variables demográficas, circunstancias del evento y tipo de tratamiento, así como la evolución de la agudeza visual y las complicaciones. Resultados: Se incluyeron 187 pacientes y 188 ojos; el promedio de edad en el momento del trauma fue de $6.99 \pm 4.1$ años. Los niños de 2-5 años (41\%) fueron los más afectados y se observó una mayor ocurrencia en el sexo masculino (73\%). El trauma ocular abierto fue el tipo de lesión más común (72.7\%), causado por objetos punzantes (45.4\%). La mayoría de las lesiones ocurrieron en casa (78.1\%), sin supervisión de un adulto (48.1\%) y durante el tiempo libre (74.9\%). La mayoría de los sucesos fueron accidentales (80.4\%), aunque el 12.3\% fue por agresiones directas. Se requirió cirugía en 179 pacientes, en quienes la reparación de lesión corneal (43.2\%) fue el procedimiento más utilizado. La agudeza visual final se cuantificó en 132 ojos y se encontró < 20/200 en el 18.1\%. Se registró la pérdida del $4.2 \%$ de los globos oculares. Conclusiones: La proporción más alta de casos se identificó en pacientes de sexo masculino $\leq 5$ años, que se encontraban sin supervisión. Una gran proporción de las lesiones oculares son prevenibles, por lo que es necesario implementar programas educativos sociales en coordinación con organizaciones pediátricas que alerten de la gravedad del problema y promuevan entornos seguros.

Palabras clave: Trauma ocular. Ceguera monocular. Promoción de la salud.

\section{Introduction}

Ocular trauma is one of the leading causes of permanent visual impairment and monocular blindness in children, significantly impacting the patient's development and quality of life ${ }^{1,2}$. The annual incidence of severe eye trauma in children is 8.85 to 15.2 cases per 100,000 inhabitants, although the frequency varies by location $^{3}$. Most children with eye trauma had a normal vision before the accident ${ }^{4}$.

Today, eye trauma is a global public health problem. The risk of eye injury in children is higher in countries with lower levels of education, such as Mexico and other Latin American countries, where there is little health promotion in accident prevention ${ }^{5}$.

As this is a potentially preventable event, it is imperative to identify its characteristics and aim for prevention. The purpose of this study was to describe the clinical characteristics and functional outcome of severe eye trauma in patients $\leq 15$ years of age who were admitted during one year to the Pediatric Emergency Department of the Hospital Civil de Guadalajara Fray Antonio Alcalde, located in western Mexico.

\section{Methods}

We conducted a retrospective, single-center, observational study, authorized by the Ethics and Research Committee of the Hospital Civil de Guadalajara, following the regulations corresponding to the Declaration of Helsinki (1964).

The study included patients $\leq 15$ years of age diagnosed with severe eye trauma admitted to the Pediatric Emergency Department of the Hospital
Civil de Guadalajara Fray Antonio Alcalde (HCFAA) from January 1 to December 31, 2017. This tertiary-level institution is a university hospital and a national reference center recognized for providing medical care to patients with a low socioeconomic level, in addition to patients who do not have other health care options.

Each clinical record was carefully reviewed to obtain detailed information. A database was used to extract relevant information for the study. Multiple variables were analyzed, such as sociodemographic characteristics, type of trauma, causes and circumstances surrounding the event, and the indicated treatment. Follow-up data were also collected to evaluate complications and measure final visual acuity.

\section{Inclusion criteria}

For this study, following clinical practice guidelines for ocular trauma in Mexico and other countries, severe ocular trauma included the following injuries: open ocular trauma, penetrating or perforating eye injuries, ocular rupture, chemical burns, and contusions involving the eye and adjacent tissues ${ }^{6}$. Severe ocular trauma can also be defined as a closed eye injury decreasing visual acuity to $<20 / 80^{7}$.

\section{Exclusion criteria}

Cases that did not require hospitalization (non-severe ocular trauma), cases that met the criteria but did not consent to hospital admission, and patients with incomplete clinical records were excluded. 


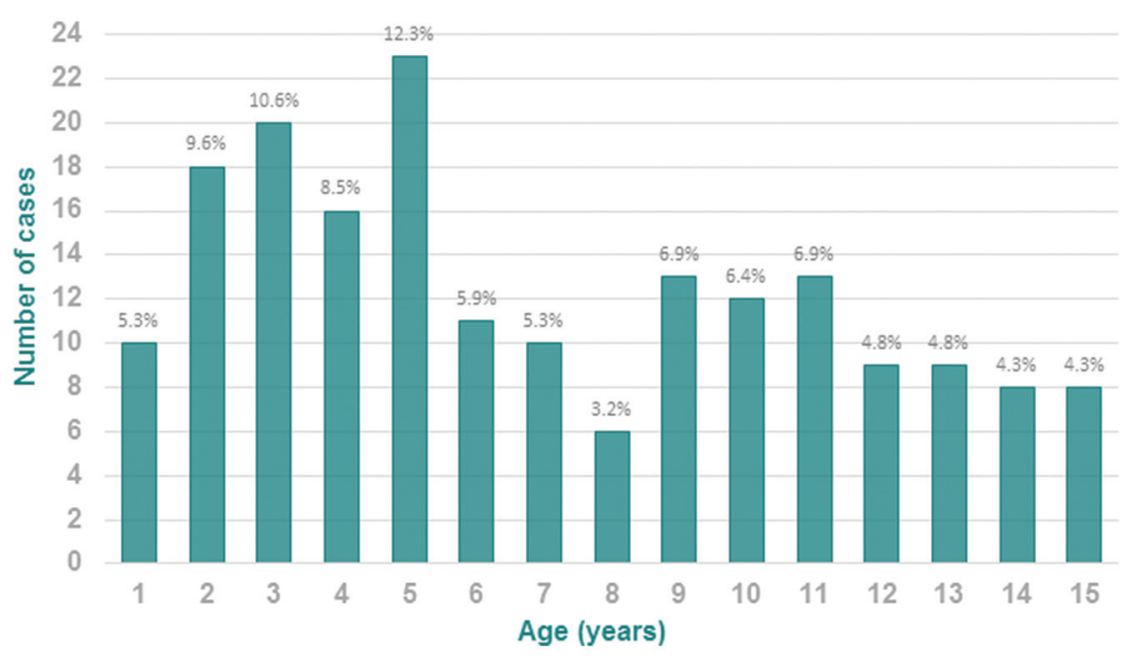

Figure 1. The number of cases per age $(n=187)$.

\section{Trauma characteristics}

The traumatic event was divided according to the circumstance in which it occurred (playing, leisure, sport, transportation, work, assault, and domestic violence); who was supervising at the time of trauma (father, mother, grandfather, none, or other), and the causative object or material (firearm, sharp object, fireworks, hand/fist, stone, animal, glass, and wood).

\section{Classification of eye trauma}

The categorization of patients and the terminology used were based on the Standardized Classification of Eye Trauma (Birmingham Eye Trauma Terminology, BETT), which classifies ocular trauma into closed and open. Open eye trauma includes ruptures and lacerations (penetrating injuries, perforating injuries, and the presence of an intraocular foreign body). Closed eye trauma includes contusions and lamellar lacerations ${ }^{8}$.

\section{Visual acuity}

For the classification of visual acuity in this study, the tenth revision of the International Classification of Diseases (ICD-10) proposed by the World Health Organization (WHO) was used. Therefore, the definition of blindness and visual impairment was classified as follows: no visual impairment ( $\geq 20 / 60$ ), mild visual impairment $(<20 / 60$ to $\geq 20 / 200)$, moderate visual impairment $(<20 / 200$ to $\geq 20 / 400)$, severe visual impairment ( $<20 / 400$ to light perception) and blindness (no light perception) ${ }^{9}$.

\section{Statistical analysis}

Data analysis was performed with SPSS version 20.0 statistical software (SPSS, Chicago, IL). Data are presented as mean, standard deviation, range, and frequency. The Poisson probability distribution model was used to calculate each month's mean probability of occurrence. $\mathrm{A} \chi 2$ test was used to compare the proportions of occurrence by month. $p$-values $<0.05$ were considered statistically significant.

\section{Results}

During the study period, 191 admissions with the diagnosis of severe ocular trauma were identified, of which four were excluded due to incomplete or insufficient clinical records. A total of 187 patients were included, with a mean \pm standard deviation (SD) age of $6.99 \pm 4.1$ years. Children aged 2 to 5 years were identified as the most affected $(41.1 \%$ of the cases) (Figure 1). Most of the patients were male $(72.7 \%)$ with a male-female ratio of 2.6:1. Most patients (47\%) resided in Guadalajara, $35 \%$ in other localities of Jalisco, and $12 \%$ in other states of the republic.

Regarding the circumstances at the time of the eye trauma, most occurred at home $(78.1 \%)$, followed by accidents outdoors and on public roads (14\%), at school $(5.2 \%)$, and in workplace environments $(2.7 \%)$. Almost 
half of the patients $(48.1 \%)$ were unsupervised by an adult at the time of the trauma, $37.4 \%$ were supervised by the father, $8 \%$ by the mother, and $6.4 \%$ were cared for by another person.

A large proportion of patients experienced the trauma during leisure time (44.4\%), $30.5 \%$ during play, $12.3 \%$ were associated with an assault, $7.4 \%$ of the cases occurred during sports, $2.7 \%$ at work, $1.6 \%$ in transportation, and $1.1 \%$ as a result of domestic violence (Table 1).

The average incidence was 15.6 cases per month during the study period, but significantly higher than expected occurrence during June, where 28 cases occurred $(p=0.002)$ (Figure 2). April, May, and June were identified as the months with significantly higher occurrence $(35.9 \%)$ than October, November, and December (18.1\%; $p=0.042)$.

Regarding the period between the incident and when medical attention was received in the emergency department, the average time was $36.13 \pm 8.27 \mathrm{~h}$ (range between $1-720 \mathrm{~h}$ ). Of the cases, $77.5 \%$ were attended within the first 24 hours after the trauma, $19.3 \%$ within 7 days, and $3.2 \%$ after one week. The mean hospital stay was $3.34 \pm 3.6$ days (range $0-30$ days). The subsequent consultations ranged from $0-12$, with a mean of $2.1 \pm 2.25$ consultations.

Concerning the characteristics of the ocular trauma, the right eye was affected in 95 cases (50.8\%); only one patient presented bilateral ocular damage. Open eye trauma occurred in 136 cases (72.3\%) and closed eye trauma in 51 cases (27.3\%). For the cases of open eye trauma, penetrating injuries were the most common type of trauma (96 cases, $51.3 \%$ ), followed by perforating wound (23 cases, $12.3 \%$ ), ruptured eyeball (10 cases, $5.3 \%$ ), and the presence of a foreign body (7 cases, $3.7 \%$ ).

The most frequent diagnoses were traumatic cataract/crystalline lens dislocation (29.9\%), vitreous hemorrhage (19\%), lacrimal duct injury (10.2\%), hyphema $(5.9 \%)$, retinal detachment $(5.3 \%)$, ruptured eyeball $(5.3 \%)$, intraorbital foreign body $(3.7 \%)$, intraretinal hemorrhage (3.2\%), and retinal rupture $(1.6 \%)$.

As for treatment, 11 patients received conservative management $(5.8 \%)$, and 176 required surgical treatment $(94.1 \%)$, even up to three surgical procedures in some patients. All procedures were performed under general anesthesia in the same hospital. Corneal wound repair was the most commonly used surgical procedure in 94 patients (50.3\%), followed by corneoscleral wound repair in 42 cases $(22.5 \%)$, dacryointubation in 18 cases (9.6\%), vitrectomy in
Table 1. Causal agent and circumstance of the event $(n=187)$

\begin{tabular}{|l|c|c|}
\hline Injury-causing object & Patients (n) & Frequency (\%) \\
\hline Sharp object & 35 & 18.7 \\
\hline Plant & 21 & 11.2 \\
\hline Glass bottle & 20 & 10.6 \\
\hline Fist & 18 & 9.6 \\
\hline Wood & 15 & 8.0 \\
\hline Animal & 12 & 6.4 \\
\hline Work tools & 11 & 5.8 \\
\hline Stone & 11 & 5.8 \\
\hline Knife/scissors & 10 & 5.3 \\
\hline Metallic bar & 8 & 4.2 \\
\hline Fireworks & 7 & 3.7 \\
\hline Toys & 6 & 3.2 \\
\hline Pen/pencil & 6 & 3.2 \\
\hline Falling on the ground & 3 & 1.6 \\
\hline Shotgun & 3 & 1.6 \\
\hline Chemical injuries & 1 & 0.5 \\
\hline Recreational activities & 157 & 2.7 \\
\hline Work-related & 5 & 13.4 \\
\hline Aggressions & 25 & \\
\hline & & \\
\hline
\end{tabular}

7 cases (3.7\%), foreign body extraction in 7 cases (3.7\%), evisceration in 5 cases $(2.7 \%)$ and lensectomy in 3 cases $(1.6 \%)$. Thirty-four patients underwent a second surgical intervention: a lensectomy in 27 , a vitrectomy in three, foreign body extraction in two, and dacryointubation in two. Twelve patients required a third procedure: 10 of them required intraocular lens placement, and two patients required foreign body extraction. The total number of surgical events was 222. Surgical complications occurred in $10 \%$ of the patients, of which $4.5 \%$ developed endophthalmitis. A total of five patients $(2.7 \%)$ lost the eyeball, and three eyes progressed to phthisis bulbi $(1.6 \%)$.

It was not possible to measure baseline visual acuity in 55 patients because of their young age and lack of cooperation. The baseline and final visual acuity of 132 eyes evaluated is described in Table 2. 


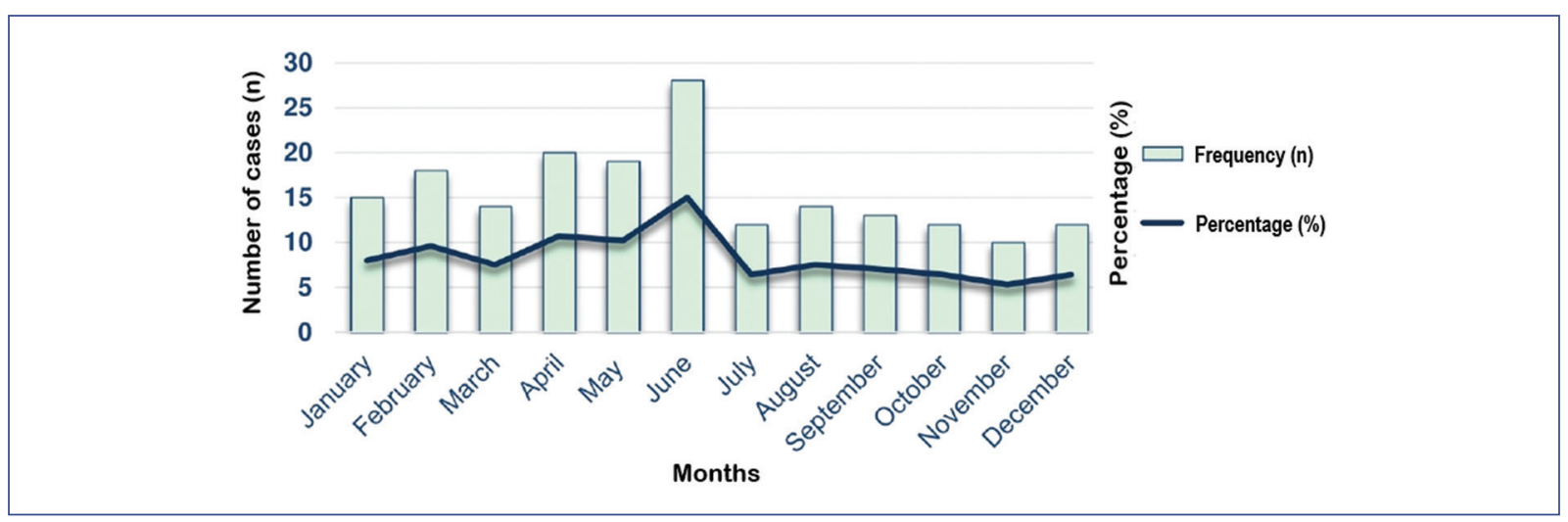

Figure 2. Distribution of ocular trauma by month (Guadalajara, Mexico, 2017).

Table 2. Visual acuity assessment before and after treatment $(n=132)$

\begin{tabular}{|l|l|c|c|c|c|c|}
\hline Characteristic & Eyes $(\mathbf{n})$ & Frequency (\%) & & Eyes (n) & Frequency (\%) \\
\hline Initial visual acuity & No light perception & 11 & 8.3 & Final visual acuity & 8 & 6.1 \\
\cline { 2 - 7 } & $<20 / 400$ to light perception & 32 & 24.2 & & 10 & 7.5 \\
\hline & $<20 / 200$ to $\geq 20 / 400$ & 20 & 15.1 & 6 & 4.5 \\
\hline & $<20 / 60$ to $\geq 20 / 200$ & 43 & 32.5 & 80 & 60.6 \\
\hline & $20 / 60$ & 26 & 19.6 & 28 & 21.2 \\
\hline
\end{tabular}

\section{Discussion}

This study analyzed aspects related to severe pediatric ocular trauma cases in the Hospital Civil de Guadalajara. Different series have revealed that only $5-20 \%$ of eye injuries require hospitalization, so ocular trauma's high frequency and impact should not be underestimate $\mathrm{d}^{10,11}$.

Consistent with other studies, our study showed that most affected children were between 2 and 11 years old and mainly were male $e^{2,4,12,13}$. These findings could be related to the type of activities and games performed, characterized by a certain level of aggressiveness and more physical contact, which puts this group at risk and makes them more susceptible to ocular trauma. Half of the affected patients were under 6 years of age, which considerably compromises the child's visual development and quality of life. Similar to other series that have reported that the highest number of cases occurs within 5-6-year-old, ${ }^{14}$ our series showed that the highest number of cases occurred at younger ages, from 2 years of age, with a peak at 5 years of age.
Most accidents occurred at home with everyday objects and with no adult supervision. Many of the patients were supervised by the father, with a ratio of 4.5:1 with respect to the mother's supervision, which could be related to the nature of the activities performed in the company of the father. Similar findings are reported in other series, indicating that supervision reduces the occurrence of childhood ocular trauma ${ }^{5}$.

When reporting employment-related ocular trauma or ocular trauma that occurred at a workplace, we should consider that some children were employed and others were accompanying their parents to help perform work-related activities, so the work environment is identified as a risk factor for childhood ocular trauma ${ }^{15}$. A study conducted in Africa showed that $39.3 \%$ of eye trauma was associated with child labor compared to $2.7 \%$ in our study ${ }^{16}$. Therefore, this percentage is relatively low compared to other countries with a higher proportion of child labor.

As for the objects identified as the cause of eye trauma, sharp objects (scissors, pencils, cables, screwdrivers, among others) were the most common. Other objects identified as causing the injury were wooden 
sticks, tree branches, and glass bottles, which increase the child's probability of eye trauma and any other type of life-threatening bodily injury.

The time between the ocular trauma and the emergency room examination was within the first 24 hours in most cases, enabling adequate treatment to be provided and reducing the probability of complications and long-term repercussions. Although not demonstrated in this case series, different studies suggest that patients receiving care $>72$ hours after trauma have a worse visual prognosis and a higher risk of complications ${ }^{17,18}$.

Similar to the cases reported in a series from the Instituto Nacional de Pediatría, Mexico City, the patients came from rural areas and low-income urban regions, with half of the cases in marginalized areas and estates far from the hospital ${ }^{12}$. The same findings are observed in other series carried out in developing countries. The latter could explain that the delay in medical care is due to the time and resources needed to transport the patient ${ }^{14}$.

The higher occurrence of cases in April, May, and June suggest a variation probably related to higher temperatures and days with longer hours of sunlight during spring and summer (or school vacation periods). This variation associate the spring and summer months with a higher incidence of cases, similar to the findings of other series ${ }^{19}$.

Most studies on ocular trauma in children report a higher incidence of closed than open ocular trauma ${ }^{2,4,20,21}$. However, only patients with severe ocular trauma requiring hospitalization were included in this study, which explains the higher frequency of open ocular trauma. The high frequency of corneal lesions and its impact on visual impairment is striking, contributing to $20-30 \%$ of the indications for corneal transplant in other series ${ }^{22,23}$.

Of the total number of patients, it was only possible to determine visual acuity in $70.5 \%$. Final visual acuity was $\geq 20 / 200$ in $18.8 \%$ of patients, consistent with other studies $^{24-26}$. However, these comparisons should be carefully reviewed since the proportion of open ocular trauma is different in each series: $47.4 \%, 51.7 \%$, and $40.6 \%$, respectively ${ }^{24-26}$. In our study, $13.6 \%$ of the affected eyes had a poor visual outcome, with a final visual acuity $\leq 20 / 400$. Unfortunately, salvage of the eye was not possible in $4.6 \%$ of the patients.

The epidemiological profiles of ocular trauma vary according to country and age group. In adults, eye trauma occurs mainly in work areas, closed ocular trauma and the intraocular foreign object being the main types of injuries. In children, eye trauma occurs mainly at home or in play areas, especially during leisure time, open ocular trauma being the most frequent type of injury. In both cases, trauma could be preventable by supervising activities and using protective eye equipment ${ }^{27}$.

A limitation of this case series would be that patients with eye injuries admitted under different diagnoses (medical records coded as multiple trauma or head injury, among other diagnoses) were omitted, which causes the occurrence of ocular trauma to be underreported.

In this study, the highest proportion of cases occurred in males $\leq 5$ years old, unsupervised, and at home. As in other studies, a large percentage of ocular trauma cases can be avoided by promoting preventive measures and raising awareness of the current situation of ocular trauma, focusing on the risks and repercussions that irreversibly affect the child's quality of life. Increased caregiver supervision and limiting young children's access to potentially dangerous objects can dramatically decrease the incidence of severe eye trauma in pediatric patients ${ }^{2,4,27}$. In alliance with pediatric organizations, it is imperative to implement educational, social programs that highlight the seriousness of the problem and promote safe environments. Prevention campaigns aimed at caregivers are crucial to avoid future accidents in pediatric patients.

\section{Ethical disclosures}

Protection of human and animal subjects. The authors declare that no experiments were performed on humans or animals for this study.

Confidentiality of data. The authors declare that they have followed the protocols of their work center on the publication of patient data.

Right to privacy and informed consent. The authors have obtained the written informed consent of the patients or subjects mentioned in the article. The corresponding author has this document.

\section{Conflicts of interest}

The authors declare no conflict of interest.

\section{Funding}

None.

\section{References}

1. Mulvihill A, Bowell R, Lanigan B, O'Keefe M. Uniocular childhood blindness: a prospective study. J Pediatr Ophthalmol Strabismus. 1997;34:111-4

2. Serrano JC, Chalela P, Arias JD. Epidemiology of childhood ocular trauma in a northeastern Colombian region. Arch Ophthalmol. 2003;121:1439-45. 
3. Abbott J, Shah P. The epidemiology and etiology of pediatric ocular trauma. Surv Ophthalmol. 2013;58:476-85.

4. Hernández LR, Hernández JR, Padilla C, Castro PD, Pons L, Estéves Y Characterization of severe ocular traumas in childhood. Rev Cubana Oftalmol. 2013;26:245-58

5. Jones O, Bacardí $P$, Paez Y, Romero L, Carcasés YA. Comportamiento clínico del trauma ocular infantil. Hospital Infantil Sur de Santiago de Cuba, 2016. Panorama Cuba y Salud. 2017;12:46-52.

6. Gobierno de Chile. Ministerio de Salud. Guía Clínica. Trauma Ocular Grave. Santiago: Ministerio de Salud; 2009. Available from: http://www.bibliotecaminsal.cl/wp/wp-content/uploads/2016/04/Trauma-Ocular-Grave.pdf

7. Gobierno Federal. Guía de Práctica Clínica. Diagnóstico y tratamiento de la contusión ocular y orbitaria. Evidencias y recomendaciones. México: Secretaría de Salud; 2010. Available from: http://www.cenetec-difusion com/CMGPC/IMSS-424-10/ER.pdf

8. Kuhn F, Morris R, Witherspoon CD, Mester V. The Birmingham Eye Trauma Terminology system (BETT). J Fr Ophthalmol. 2004;27:206-10.

9. International Statistical Classification of Diseases and Related Health Problems. Geneva: World Health Organization; 2019. Available from: https://icd.who.int/browse10/2019/en\#/H54.3

10. May DR, Kuhn FP, Morris RE, Witherspoon CD, Danis RP, Matthews GP et al. The epidemiology of serious eye injuries from the United States Eye Injury Registry. Graefes Arch Clin Exp Ophthalmol. 2000;238:153-7.

11. León Hernández FA, Taboada Esteve JF. Traumatismos oculares graves en España: factores epidemiológicos, estudio de las lesiones y medidas de prevención. Barcelona: Domènec Pujades; 1994.

12. Ugalde R, Ordaz JC, Salazar JA. Trauma ocular en niños: experiencia en el Instituto Nacional de Pediatría. Rev Mex Oftalmol. 2000:74:11-6.

13. El-Sebaity DM, Soliman W, Soliman AM, Fathalla AM. Pediatric eye injuries in upper Egypt. Clin Ophthalmol. 2011;5:1417-23.

14. Al Wadeai EA, Osman AA, Macky TA, Soliman MM. Epidemiologica features of pediatric ocular trauma in Egypt. J Ophthalmol. 2016;2016:1-6.

15. López-Limón MG. La fuerza de trabajo infantil en México. Ciudad de México: III Conferencia de la Red Latinoamericana y del Caribe de Childwatch International; 2002. Available from: https://programainfancia. uam.mx/pdf/iii_chw/lopezlimon_mx.pdf.
16. Isawumi MA, Adebayo M. Child abuse and the eye in an African population. Korean J Ophthalmol. 2017;31:143-50.

17. Wallace HB, Ferguson RA, Sung J, McKelvie J. New Zealand adult ocular trauma study: a 10-year national review of 332418 cases of ocular injury in adults aged 18 to 99 years. Clin Exp Ophthalmol. 2020;48:158-68

18. Zhang L, Liu Y, Chen S, Wang Y. [Clinical observation of the vitreous surgery for open-globe injuries in different timing after the trauma]. Zhonghua Yan Ke Za Zhi. 2014;50:121-5.

19. Bhagat N, Nagori S, Zarbin M. Post-traumatic infectious endophthalmitis. Surv Ophthalmol. 2011;56:214-51.

20. Oiticica-Barbosa MM, Kasahara N. Eye trauma in children and adolescents: perspectives from a developing country and validation of the ocular trauma score. J Trop Pediatr. 2015;61:238-43.

21. Razo DM, Pérez XI, Sánchez MF, Lima V. Estimación del daño por trauma ocular en Pediatría sin la evaluación de la agudeza visual. Bol Med Hosp Infant Mex. 2011:68:363-68.

22. Stulting RD, Sumers KD, Cavanagh HD, Waring GO $3^{\text {rd }}$, Gammon JA. Penetrating keratoplasty in children. Ophthalmology. 1984;91:1222-30.

23. Dana MR, Moyes AL, Gomes JA, Rosheim KM, Schaumberg DA, Laibson PR, et al. The indications for and outcome in pediatric keratoplasty. A multicenter study. Ophthalmology. 1995;102:1129-38.

24. Puodžiuvienė E, Jokūbauskienė G, Vieversytė M, Asselineau K. A five-year retrospective study of the epidemiological characteristics and visual outcomes of pediatric ocular trauma. BMC Ophthalmol. 2018;18:10.

25. Shoja MR, Miratashi AM. Pediatric ocular trauma. Acta Med Iran. 2006;44:125-30

26. Al-Mahdi HS, Bener A, Hashim SP. Clinical pattern of pediatric ocular trauma in fast-developing country. Int Emerg Nurs. 2011;19:186-91.

27. Díaz-Mendoza JJ, Chirinos-Saldaña MP, Uribe-Villarreal J, Hilario-Vargas J, Adrianzén RE. Características epidemiológicas de los traumatismos oculares en un instituto oftalmológico de referencia regional, Trujillo Perú, 2016-2017. Acta Med Peru. 2019;36:281-6. 